RELATIONSHIPS BETWEEN WATER QUALITY AND PHOSPHORUS CONCENTRATIONS FOR LAKES OF THE PUGET SOUND REGION, WASHINGTON

By R. J. GILLIOM and G. C. BORTLESON

U.S. GEOLOGICAL SURVEY

OPEN FILE REPORT 83-255 
UNITED STATES DEPARTMENT OF THE INTERIOR

JAMES G. WATT, Secretary

GEOLOGICAL SURVEY

Dallas L. Peck, Director

For additional information write to:

Chief Hydrologist

U.S. Geological Survey

410 National Center

Reston, Virginia 22092 
Abstract....................................... 1

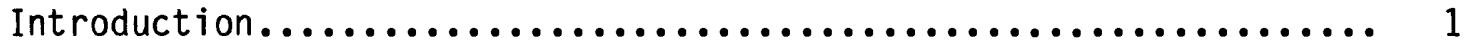

Study Area.......................................... 2

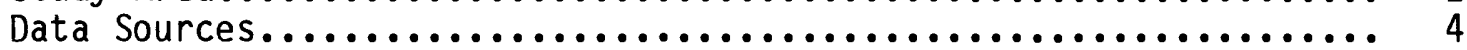

Phosphorus in Puget Sound Region Lakes..................... 4

Phosphorus Limitation............................... 4

Phosphorus Levels and Seasonal Variation.................. 6

Phosphorus and Water Quality.......................... 8

Algal Biomass...................................... 10

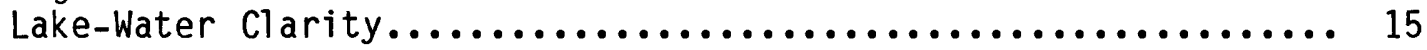

General Water-Quality Groups......................... 21

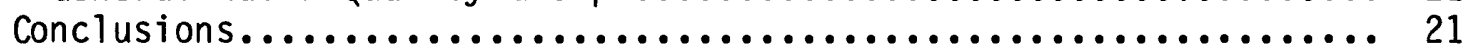

Literature Cited.................................... 23

\section{ILLUSTRATIONS}

Figure 1.--Puget Sound region and locations of 17 lakes used in

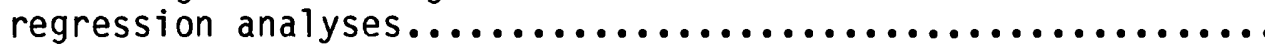

Figure 1.--Relationship between summer and winter-spring concentrations of total phosphorus in near-surface lake waters. All lakes stratify during the summer..............

Figure 3.--Relationship between summer chlorophyll a and winterspring total phosphorus concentrations.................. 11

Figure 4.--Relationship between summer chlorophyll a and summer total phosphorus concentrations....................... 12

Figure 5.--Relationship between summer Secchi-disc transparency and summer cholorophyll a concentration................. 16

Figure 6.--Relationship between summer Secchi-disc transparency and summer total phosphorus concentration............... 18

Figure 7.--Relationship between summer Secchi-disc transparency and summer total phosphorus concentration for lakes with phosphorus concentrations of $15 \mathrm{ug} / \mathrm{L}$ or greater..............

\section{TABLES}

Table 1.--Data sources and characteristics.................. 5

Table 2.--Mass ratios of nitrogen to phosphorus in lakes and

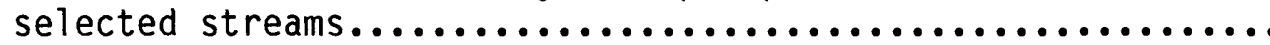

Table 3.--Comparison of regression models for estimating summer chlorophyll a concentrations from total phosphorus

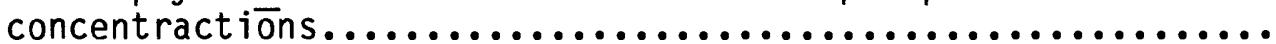

Table 4.--Comparison of regression models for estimating summer secchi-disc transparency from total phosphorus concentration. 20

Table 5.--Characteristic relationships between lake-water phosphorus concentrations, and general lake-water quality.... 22 


\title{
RELATIONSHIPS BETWEEN WATER QUALITY AND PHOSPHORUS CONCENTRATIONS FOR LAKES OF THE PUGET SOUND REGION, WASHINGTON
}

\author{
By R. J. Gilliom and G. C. Bortleson
}

\begin{abstract}
Predictive regression relationships between concentrations of total phosphorus (P) in near-surface waters $(1 \mathrm{~m})$ and water-quality characteristics were developed for lakes in the Puget Sound region. Nitrogen-to-phosphorus ratios support the strategy of emphasizing total $P$ for lake eutrophication assessment within the range of lake conditions represented. Relationships based on summer total $P$ concentrations, rather than winter-spring total $P$, led to more successful prediction of mean summertime chlorophyll a concentrations and Secchi-disc transparencies. The 78 lakes evaluated in the study had an average mean concentration of total phosphorus in near-surface waters of $22 \mu \mathrm{g} / \mathrm{L}$ during the summer with mean concentrations for individual lakes ranging from 7 to $76 \mu \mathrm{g} / \mathrm{L}$. For regression relationships based on summer total phosphorus concentrations, the standard error of predicted Secchi-disc transparencies is \pm 0.9 meters for phosphorus concentrations of $15 \mathrm{\mu g} / \mathrm{L}$ or greater, and the standard error of predicted chlorophyll a concentrations is $\pm 5 \mu \mathrm{g} / \mathrm{L}$. Predictions for the range of conditions evaluated favorably agreed with predictions from similar relationships developed by other researchers for different lakes. To supplement estimates of transparency and chlorophyll a from regression relationships, a broader system of water-quality groups, including recreational suitability and fish habitat quality, was developed from published information and our experience in the region.
\end{abstract}

\section{INTRODUCTION}

Eutrophication, the natural aging process of lakes, is often greatly accelerated by additions of nutrients resulting from human activities. Such nutrient fertilization often results in excessive growths of algae and other aquatic plants, which can interfere with the beneficial uses of water for recreation, fisheries, and domestic water supply. Many lakes in the Puget Sound region are threatened by eutrophication-related water-quality problems related to increased nutrient inputs from urban and agricultural land uses in their watersheds. The large number of lakes in this region and the increasing use of these lakes and development in their drainage basins make anticipation and control of eutrophication a pressing and difficult task for local and State agencies.

The most cost-effective approach to managing eutrophication is usually to prevent or reduce the supply of nutrients to a lake. The rate of supply of forms of $P$ (phosphorus) and $N$ (nitrogen) that are available to algae generally limits the maximum biomass of algae in a lake. Phosphorus is the limiting and most controllable nutrient affecting algal productivity in most lakes in 
temperate regions of the world (Vollenweider, 1968; Schindler and Fee, 1974; Schindler, 1978; Rast and Lee, 1978). Phosphorus concentration is a common criterion used to classify lakes according to general productivity level (Rast and Lee, 1978), and there is a strong correlation between total $P$ concentrations and chlorophyll a concentrations, the latter being an indirect measure of algal biomass (Sakkamoto, 1966; Dillon and Rigler, 1975; Jones and Bachmann, 1976; Schindler and others, 1978).

In recent years, statistical models that relate lake-water $P$ concentrations and water-quality characteristics (for example, chlorophyll a concentration and Secchi-disc transparency) have played a significant role in managing eutrophication. The predictive accuracy of such models, however, depends largely on how well the data used to formulate them represent actual conditions at lakes for which predictons are needed. Models developed from data for one region may not always work well for another region. Such models are not well developed for the Puget Sound region.

The purpose of this study was to formulate predictive relationships between lake-water $P$ concentrations and algal biomass and lake-water clarity for use in the Puget Sound region. These methods, if sufficiently precise for a particular application, allow water-quality managers in this region to predict the waterquality response of a lake to various P-control management practices and weigh costs of nutrient-control options against potential water-quality improvement benefits. The application of each method is explained along with its derivation. The methods developed in this study complement previously developed methods for estimating background (predevelopment) P loadings and concentrations (Gilliom, 1981), and P loadings from nonpoint sources (Gilliom, 1982).

\section{STUDY AREA}

All the lakes included in this study are located within the Puget Sound region (fig. 1). Most are lowland lakes that occupy depressions in glacial till or outwash deposited by the most recent continental glaciation. Soils surrounding the lakes are mainly shallow, gravelly sandy loam with local deposits of peat, muck, and fine-textured soils. Native vegetation is dominated by dense growths of conifers and associated shrubs, but most merchantable timber has been harvested at least once, resulting in a mixed forest containing both conifers and deciduous trees.

The mixing and flushing cycles of lakes in the study area are controlled by the area's climate. The region is characterized by a mild maritime climate with annual precipitation ranging from about $0.5 \mathrm{~m}$ to more than $3.0 \mathrm{~m}$, depending mainly on elevation and location with respect to the region's mountain ranges. About 80 percent of the precipitation occurs from October through April. Surface-water inflows and lake flushing are also greatest during the winter season for most lakes, and during this period the lakes are completely mixed. Thermal stratification of lake water commonly begins in May and continues through September or early 0ctober. Most lakes with mean depths greater than $3 \mathrm{~m}$ remain stratified the entire summer. 


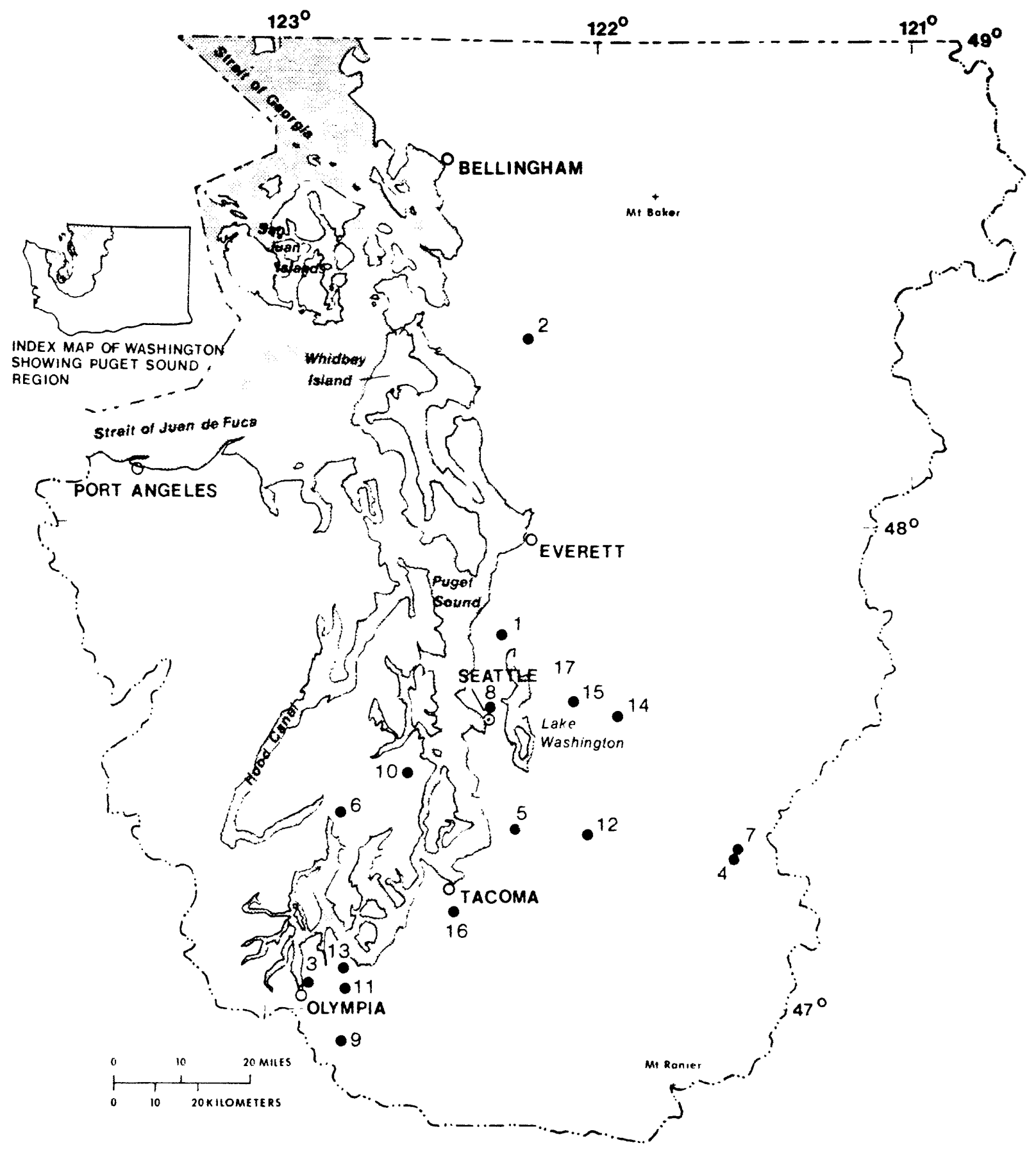

Figure 1. Puget Sound region and locations of 17 lakes used in regression analyses. 


\section{DATA SOURCES}

Data used in the present study were collected in several previous studies by other investigators from a total of 78 lakes. The sources and nature of these data are given in table 1. Seventeen of the lakes had been sampled at least once each month. For some of these lakes, data were available for more than one sampling period. The locations of the 17 lakes are shown in figure 1. The remaining 61 lakes were sampled quarterly for a one-year period. These 61 lakes are scattered throughout the Puget Sound region and their locations are not shown. In general, we relied mainly on data from the 17 intensively studied lakes in our analyses.

Entries in table 1 for lakes numbered 1-17 represent a total of 25 separate observations of mean conditions in near-surface waters sampled at about 1-m depth that include, for both winter-spring and summer periods:

Total P

Dissolved $\mathrm{PO}_{4}-\mathrm{P}$ (orthophosphate or "soluble reactive" phosphorus)

Total $\mathrm{N}$

Dissolved inorganic $\mathrm{N}$

Chlorophyll a

Secchi-disc Eransparency

For some lakes, data were not adequate for including all the terms, and those missing are indicated in table 1. Thus, not all the analyses in this report include all 25 observations for the 17 lakes.

In data analyses, each observation is consistently identified according to the numbering system in table 1. For data source 18, which comprises data from a quarterly sampling program, we grouped data by $P$ concentration ranges, so that data for several of these less intensively studied lakes were averaged. This step yielded four or five observations (depending on whether data were grouped by winter-spring or summertime $P$ levels) which were treated as equivalent in statistical weight to one period of intensive study of one of the lakes in the 17-lake group. These groups were designated by $18 a, b, c, d$, and $e$. Unless otherwise noted, all water-quality data discussed in this report except for Secchi-disc transparency are for near-surface waters.

\section{PHOSPHORUS IN PUGET SOUND REGION LAKES}

\section{Phosphorus Limitation}

Basic nutritional requirements of algae, and studies using cultures of algae in laboratories show that $N$ usually limits algal growth if the mass ratio of $N$ to $P$ is less than 5:1 (Rast and Lee, 1978). Conversely, $P$ usually limits if the ratio is greater than 10:1. Between ratios of about $5: 1$ and 10:1, either $N$ or $P$ could be limiting factors, especially in natural lake systems with complex algal communities. These ratios, in theory, refer to the amounts of $N$ and $P$ in forms that are readily usable by algae. The available form of $\mathrm{P}$ is dissolved $\mathrm{PO}_{4}$, and the available forms of $\mathrm{N}$ are mainly dissolved $\mathrm{NH}_{4}$ (ammonia) and $\mathrm{NO}_{3}$ (nitrate), though some algae can fix $\mathrm{N}_{2}$ (nitrogen gas) 
TABLE 1. Data sources and characteristics

\begin{tabular}{|c|c|c|c|c|c|c|c|}
\hline & Lake & tification & $\begin{array}{l}\text { Sampling } \\
\text { period }\end{array}$ & $\begin{array}{l}\text { Water } \\
\text { column } \\
\text { sampling }\end{array}$ & $\begin{array}{l}\text { Approximate } \\
\text { sampling } \\
\text { frequency } \\
\end{array}$ & $\begin{array}{l}\text { Missing } \\
\text { data } 1 /\end{array}$ & Investigator \\
\hline 1. & Ballinger & yes & $\begin{array}{l}\text { June } 1975 \\
\text { Dec. } 1976\end{array}$ & Epilimnion & $\begin{array}{l}\text { Biweekly and } \\
\text { monthly }\end{array}$ & STN, WTN & Welch and others (1977) \\
\hline 2. & Big & no & $\begin{array}{l}\text { June } 1976- \\
\text { July } 1977\end{array}$ & $1 \mathrm{~m}$ & $\begin{array}{l}\text { Biweekly and } \\
\text { monthly }\end{array}$ & $\begin{array}{l}\text { SON, WDN, } \\
\text { STN, WTN }\end{array}$ & URS Company (1977) \\
\hline 3. & Capital Lake & yes & $\begin{array}{l}\text { Apr. } 1974- \\
\text { Jan. } 1975\end{array}$ & $\begin{array}{l}\text { Water-column } \\
\text { composite }\end{array}$ & Monthly & SDN,WDN & Orsborn and others (1975) \\
\hline 4. & Chester Morse & yes & $\begin{array}{l}\text { a. } 1971 \\
\text { b. Summer } 1973\end{array}$ & $\begin{array}{l}\text { Photic zone } \\
\text { Photic zone }\end{array}$ & $\begin{array}{l}\text { Biweekly } \\
\text { Monthly }\end{array}$ & $\begin{array}{l}\text { SCHLA } \\
\text { WTP, WDP, SDN, } \\
\text { WON, STN,WTP }\end{array}$ & $\begin{array}{l}\text { Hendrey (1973) } \\
\text { Birch (1976) }\end{array}$ \\
\hline 5. & Fenwick & yes & May-Dec. 1979 & $\begin{array}{l}\text { Composite from } \\
\text { surface to } 3 \mathrm{~m}\end{array}$ & Weekly & 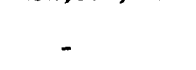 & URS Company (1977) \\
\hline 6. & Fern & yes & 1960 & Epilinnion & Biweekly & $\begin{array}{l}\text { WTP, WDP, STN, } \\
\text { WTN, SON, WDN }\end{array}$ & Stamines (1972) \\
\hline 7. & Findley & yes & Summer 1974 & Photic zone & Monthiy & $\begin{array}{l}\text { WTP, WDP, STN, } \\
\text { WTN, SDN, WDN }\end{array}$ & Birch (1976) \\
\hline 8. & Green & no & $\begin{array}{ll}\text { a. } & 1959 \\
\text { b. } & 1965 \\
\text { c. } & 1966\end{array}$ & Surface and $3 \mathrm{~m}$ & Biweekly & $\begin{array}{l}\text { STN, WTN, } \\
\text { SDN, WDN }\end{array}$ & Oglesby (1969) \\
\hline 9. & Hicks & yes & $\begin{array}{l}\text { Sept. } 1976- \\
\text { Sept. } 1977\end{array}$ & Surface & Monthly & SCHLA & $\begin{array}{l}\text { George Edwards, } \\
\text { Entranco Engineers, } \\
\text { written comnun. (1980) }\end{array}$ \\
\hline 10. & $\begin{array}{l}\text { Long } \\
\text { (Kitsap Co.) }\end{array}$ & no & $\begin{array}{l}\text { a. July } 1976 \text { - } \\
\text { Dec. } 1977\end{array}$ & $\begin{array}{l}\text { Surface, mid, and } \\
\text { near bottom (average) }\end{array}$ & $\begin{array}{r}\text { Weekly and } \\
\text { biweekly }\end{array}$ & - & Perkins and others (1979) \\
\hline & & & $\begin{array}{l}\text { D. Oct. } 1977 \text { - } \\
\text { June } 1978\end{array}$ & $\begin{array}{l}\text { Surface and } \\
\text { middepth }\end{array}$ & Monthiy & - & Welch and others (1979) \\
\hline 11. & $\begin{array}{l}\text { Long } \\
\text { (Thurston Co.) }\end{array}$ & yes & $\begin{array}{l}\text { Sept. } 1976= \\
\text { Sept. } 1977\end{array}$ & Surface & Monthly & SCHLA & $\begin{array}{l}\text { George Edwards, } \\
\text { Entranco Engineers, } \\
\text { written commun. (1980) }\end{array}$ \\
\hline 12. & Meridian & yes & $\begin{array}{l}\text { July } 1976- \\
\text { June } 1977\end{array}$ & Epilinnion & Biweekly & STN,WTN & $\begin{array}{l}\text { Davis and others (1978) } \\
\text { George Edwards, }\end{array}$ \\
\hline 13. & Patterson & yes & $\begin{array}{l}\text { Sept. } 1976- \\
\text { Sept. } 1977\end{array}$ & Surface & Monthly & SCHLA & $\begin{array}{l}\text { Entranco Engineers, } \\
\text { written commun. (1980) }\end{array}$ \\
\hline 14. & Pine & yes & 1971 & Epilimnion & Biweekly & $\begin{array}{l}\text { WTP, WDP, STN, } \\
\text { WTN, SDN, WDN }\end{array}$ & Stammes (1972) \\
\hline \multirow[t]{2}{*}{15.} & Sammanish & yes & a. $1964-65$ & $1 \mathrm{~m}$ & $\begin{array}{l}\text { Weekly and } \\
\text { biweekly }\end{array}$ & $\begin{array}{l}\text { SDP, WDP, STN, } \\
\text { WTN, SDN, WDN }\end{array}$ & Issac and others (1966) \\
\hline & & & b. $1970-74$ & $\begin{array}{l}\text { Photic zone } \\
(\text { to } 7.3 \mathrm{~m})\end{array}$ & Monthly & $\begin{array}{l}\text { STN, WTN, } \\
\text { WDN }\end{array}$ & Welch and others (1975) \\
\hline 16 & Wapato & no & Feb.-Sept. 1975 & $1 \mathrm{~m}$ & Monthly & - & Dion and others (1980) \\
\hline 17. & Washington & yes & $\begin{array}{ll}\text { a. } & 1957 \\
\text { b. } & 1962 \\
\text { c. } & 1970 \\
\text { d. } & 1976\end{array}$ & Surface to $10 \mathrm{~m}$ & Weekly & - & $\begin{array}{l}\text { W. T. Edmondson, } \\
\text { University of Washington, } \\
\text { written commun. (1980) }\end{array}$ \\
\hline 18. & $\begin{array}{l}61 \text { selected lakes } \\
\text { in Puget Sound } \\
\text { region }\end{array}$ & yes & $1972-75$ & $1 \mathrm{~m}$ & Quarterly & - & $\begin{array}{l}\text { Bortleson and others }(1974) \\
\text { Bortleson and others }(1976) \\
\text { McConnell and others }(1976) \\
\text { Dion and others }(1976) \\
\text { Dion and others }(1980)\end{array}$ \\
\hline
\end{tabular}


and use it. But ratios of total $N$ to total $P$ in lake water are also useful because they indicate which nutrient would be limiting if all forms present were converted to available forms.

Application of the limiting-nutrient concept to lake management is not without problems. For example, it is likely that a mixed phytoplankton population would respond to the addition of either $N$ or $P$, especially in those lakes in which the ambient $N: P$ ratio is intermediate between $N$ and $P$ limitation. Also, different species within an algal community may be limited by different nutrients simultaneously, and some lakes may frequently shift from one limiting nutrient to the other. In addition, $N$ and $P$ are recycled so rapidly that measured concentrations of their dissolved forms are not necessarily indicative of available supply (see next section). In general, however, $N: P$ ratios are a useful tool for determining which nutrient should ideally be reduced to best control eutrophication. Reducing the amount of the limiting nutrient will generally achieve the greatest reduction in algal growth. To achieve the greatest improvement in water quality with the least cost, however, costs of reducing nutrients other than the one thought to be limiting should al so be evaluated because control costs may vary widely.

In this study, mass ratios of $N$ to $P$ were calculated for Puget Sound region lakes and for selected streams for both winter and summer periods. Data for all lakes cited in table 1 were used, and for analysis of N:P ratios, data for all 61 lakes included in data-source 18 were treated individually. Table 2 shows a summary of results both for available forms of the nutrients (streams and lakes) and total amounts present in the water (lakes only). For the lakes, median ratios ranged from 24:1 for total $N$ and total $P$ during the stratified period to 72:1 for available forms of $N$ and $P$ during nonstratified periods. Only one of the 78 lakes had a ratio of available $N$ to available $P$ amounting to less than 5:1. Only 3 to 6 lakes (depending on season and nutrient form) had similar ratios between 5:1 and 10:1. More than 90 percent of the 1 akes in each category had ratios greater than 10:1. Results for 36 streams were similar; 32 had $\mathrm{N}$-to-P ratios greater than 10:1. These data strongly suggest that algal growth in all but a few lakes and streams in this region is $P$ limited. The clear prevalence of $P$ limitation makes evaluation and control of $P$ sources the most important focus of efforts to control eutrophication in the region's lakes and streams.

\section{Phosphorus Levels and Seasonal Variation}

The concentration of total $P$ in lake water is the most common type of $P$ measurement used for deriving relationships between $P$ and water-quality characteristics. Total $P$ includes dissolved organic $P, P$ in living algae, $P$ associated with dead particulate matter, and dissolved $\mathrm{PO}_{4}$. Though dissolved $\mathrm{PO}_{4}$ (the form immediately available to algae) may be less than 5 percent of the total $P$ at any one time (Wetzel, 1978), the pool of P associated with particulate matter is constantly being converted to dissolved $\mathrm{PO}_{4}$ by chemical and biological processes. Unless there is much inorganic particulate matter present, therefore, total-P concentration tends to be the best indicator of the total amount of $P$ potentially involved in algal growth. Preliminary evaluations of our data tended to confirm this by showing poor correlations between dissolved $\mathrm{PO}_{4}$ and amounts of algae present. Therefore, the remainder of this report focuses only on relationships between total $P$ and water-quality characteristics. 
TABLE 2. Mass ratios of nitrogen to phosphorus in lakes and selected streams

$$
\text { Type of ratiol/ }
$$

Statistic

\begin{tabular}{llll}
\hline STN:STP & WTN:WTP & SDN:SDP & WDN:WDP \\
\hline \multicolumn{4}{c}{ Lakes }
\end{tabular}

\begin{tabular}{lrrrr}
\hline Number of lakes & 73 & 74 & 78 & 76 \\
$\begin{array}{l}\text { Number of lakes } \\
\text { with ratios: }\end{array}$ & & & & \\
$\quad<5$ ratio $<10$ & 1 & 1 & 1 & 0 \\
$5<$ ra & 68 & 69 & 71 & 3 \\
$\quad$ Median ratio & 24 & 28 & 40 & 72 \\
$\begin{array}{l}\text { Mean ratio } \pm \\
\text { standard deviation }\end{array}$ & $29 \pm 16$ & $35 \pm 26$ & $66 \pm 72$ & $124 \pm 133$ \\
\hline
\end{tabular}

Streams 2 I

\begin{tabular}{|c|c|c|c|c|}
\hline Number of streams & - & - & 36 & 36 \\
\hline \multicolumn{5}{|l|}{ Number of streams } \\
\hline$<5$ & - & - & 0 & \\
\hline $5<$ ratio $<10$ & - & - & 4 & 0 \\
\hline$>10$ & - & - & 32 & 36 \\
\hline Median ratio & - & - & 40 & 47 \\
\hline $\begin{array}{l}\text { Mean ratio } \pm \\
\text { standard deviation }\end{array}$ & - & - & $73 \pm 9$ & $79 \pm 14$ \\
\hline
\end{tabular}


For Puget Sound region lakes included in this study, the average mean summertime total $P$ concentration is $22 \mu \mathrm{g} / \mathrm{L}$, and the median concentration is $16 \mu \mathrm{g} / \mathrm{L}$. The average mean winter concentration of total $P$ is $27 \mu \mathrm{g} / \mathrm{L}$, and the median is $25 \mu \mathrm{g} / \mathrm{L}$. However, these seasonal variations appear to be different in lakes that stratify during the summer compared to those that do not.

The regression relationship between the summer and the winter-spring measurements of total $P$ for stratified lakes is shown in figure 2, and may be expressed as follows:

$$
S T P=0.75 \cdot W T P
$$

where STP is summer total $P$ and WTP is winter-spring total $P$. As this equation indicates, total $P$ concentrations average about 75 percent of winter-spring concentrations, with winter-spring concentrations explaining 69 percent of the variance in concentrations the following summer (see fig. 2). Data source 18 in table 1, though not included in this regression analysis, showed that 31 of 42 stratified lakes in that group had summer total $p$ levels that were less than winter levels. For unstratified lakes, the situation is less clear. Data for the four unstratified lakes $(2,8 a, 10 a, 10 b, 16)$ in table 1 indicate that summer and winter-spring total $P$ concentrations are, on the average, about equal. Five observations for the four lakes showed a range of STP/WTP of 0.67-1.2 and a mean of 0.97. The absence of thermal stratification, if this small sample is representative, appears to reduce a lake's tendency to trap $P$ in bottom waters or sediments during the summer, thus resulting in relatively constant mean concentrations throughout the year even though loading is usually small in the summer. In fact, as found by Welch and others (1979) for Long Lake (lake 10), a value of STP/WTP greater than 1.0 suggests an internal source of $P$ during the summer. Stratified lakes, in contrast, probably have relatively low summer total $P$ concentrations compared to winter concentrations because $P$ that settles to deep waters is effectively trapped below the thermocline.

\section{PHOSPHORUS AND WATER QUALITY}

The adverse effects that increased phosphorus concentration has on lakewater quality are indirect effects related to corresponding increases in algal growth. The presence of more algae leads to reduction of water clarity and depletion of oxygen in the hypolimnion of a lake when dead organisms settle to the lake bottom and decay. Murky water or floating scums of algae generally do not appeal to recreationists, and low concentrations of dissolved oxygen can cause injury to fish. (For estimating the impact of specific $P$ levels on oxygen depletion, the reader is referred to Walker [1980] and Welch and Perkins [1979].) In this study, we have focused on developing statistical relationships between total $P$ concentrations and water-quality variables that are easily evaluated from available data: algal biomass (as indicated by chlorophyll a concentration) and water clarity (as indicated by Secchi-disc transparency).

Predictive relationships were developed using linear-regression analysis of the data described in table 1. In some cases, variables were transformed to allow treatment of relationships that are apparently nonlinear. For all methods presented, standard error estimates for individual predictions are provided, which represent 68-percent-confidence bounds. All values for chlorophyll 


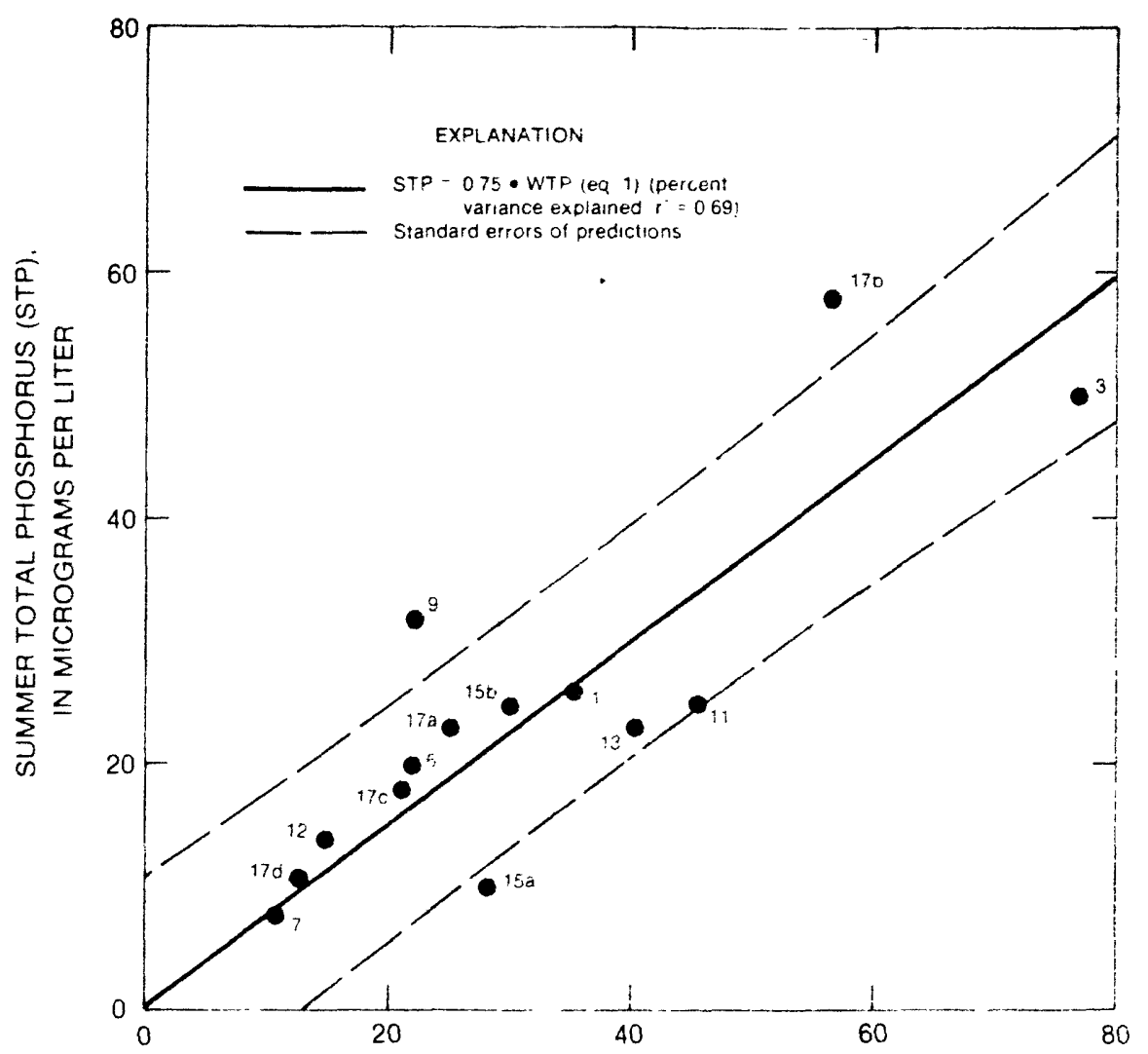

WINTER-SPRING TOTAL PHOSPHORUS (WTP), IN MICROGRAMS PER LITER

Figure 2. Relationship between summer and winter-spring concentrations of total phosphorus in near-surface lake waters All lakes stratify during the summer. (Numbers at plots identify lake and description of data, as listed in table 1.) 
a and Secchi-disc depth are for the summer season, which is the peak season for recreational use of Puget Sound region lakes and is the most important time to achieve water-quality goals.

\section{Algal Biomass}

The concentration of chlorophyll a, a major photosynthetic pigment in algae, is an easily measured and usefuT indicator of the amount of algae in water. Chapra and Tarapchak (1976) reviewed relationships between chlorophyll a levels and lake productivity of biomass. In general, mean summer chlorophyll $\bar{a}$ concentrations that average less than $3 \mu \mathrm{g} / \mathrm{L}$ indicate low-productivity lakes, concentrations between 3 and $9 \mu \mathrm{g} / \mathrm{L}$ indicate medium productivity lakes; and average concentrations greater than $9 \mu \mathrm{g} / \mathrm{L}$ indicate lakes with high productivity.

In this study, we evaluated relationships between summer chlorophyll a (SCHLA) and both winter-spring total $P$ and summer total $P$. Winter-spring Eotal $P$ concentration has been used by other investigators as an index of the amount of $P$ available for algal growth at the onset of the summer growing season and for predicting summer chlorophyll a levels (Dillon and Rigler, 1974; Chapra and Tarapchak, 1976; and Oglesby and Schaffner, 1978). Summer epilimnion total $P$ levels, which more directly represent the amount of $P$ actually involved in algal growth during the summer growing season, have also been successfully used to predict summer chlorophyll a concentration (Jones and Bachman, 1976).

Relationships found between total $P$ and chloropyll a concentrations for Puget Sound region lakes are shown in figures 3 and 4 . The expressions for the regression relationships are given as follows:

$$
\begin{aligned}
& \text { SCHLA }=0.37 \cdot W T P-2.1 \\
& \text { SCHLA }=0.42 \cdot S T P-2.0
\end{aligned}
$$

where SCHLA is summer chlorophyll a concentration and WTP and STP are as defined for equation 1. Observations $8 b$ and $8 c$ from Green Lake were not included in the evaluation shown in figure 3 because artificial dilution altered natural seasonal fluctuations in $P$ levels in the years of those observations. In both figures 3 and 4 , both stratified and unstratified lakes were included. Lakes that may have been $\mathrm{N}-\mathrm{limited}$, as determined by a ratio of mean summer inorganic $\mathrm{N}$ concentration to dissolved $\mathrm{PO}_{4}-\mathrm{P}$ less than 10 , are so indicated.

The results shown in figures 3 and 4 raise some interesting questions for discussion. One might expect, because unstratified lakes tend toward nearly equal summer and winter total $P$ concentrations, that unstratified lakes would have more algae in the summer, for equal amounts of winter $P$, than would stratified lakes (in which summer $P$ concentrations average distinctly less than winter P). Figure 3 does not clearly show this, however. Furthermore, figure 4 suggests that there may be less chlorophyll a per unit of summer total $P$ in unstratified lakes as compared to stratified lakes. The data from unstratified lakes depicted in both figures 3 and 4 may be explained by the reasoning that there is likely to be a greater portion of the near-surface total $P$ in these lakes that is unavailable for algal growth. This could result from a relatively high rate of resuspension of P-bearing particulate matter in unstratified lakes due to their shallow, completely mixed character. Such a condition would cause 


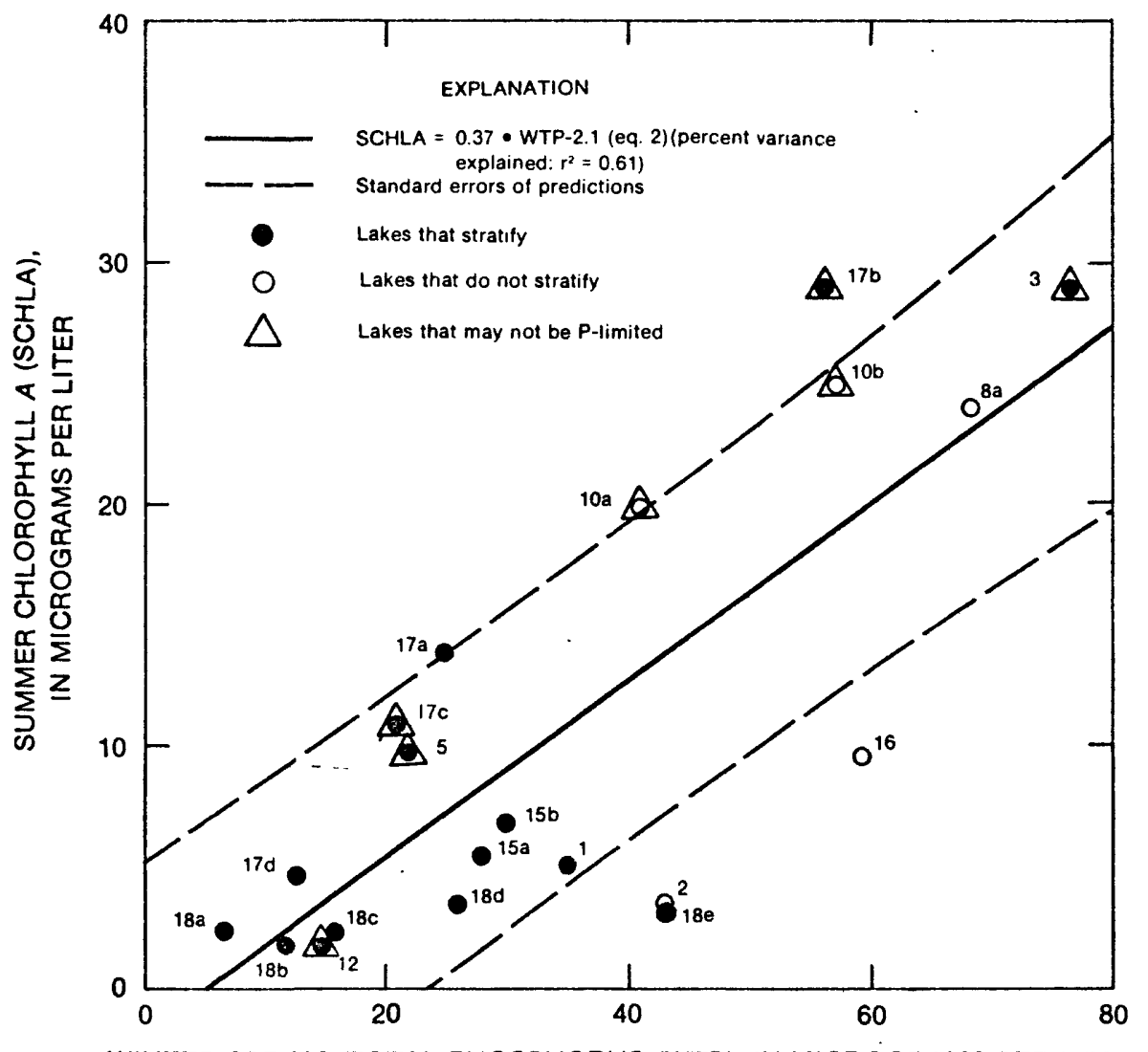

WINTER-SPRING TOTAL PHOSPHORUS (WTP), IN MICROGRAMS PER LITER

Figure 3. Relationship between summer chlorophyll a and winter-spring total phosphorus concentrations. 


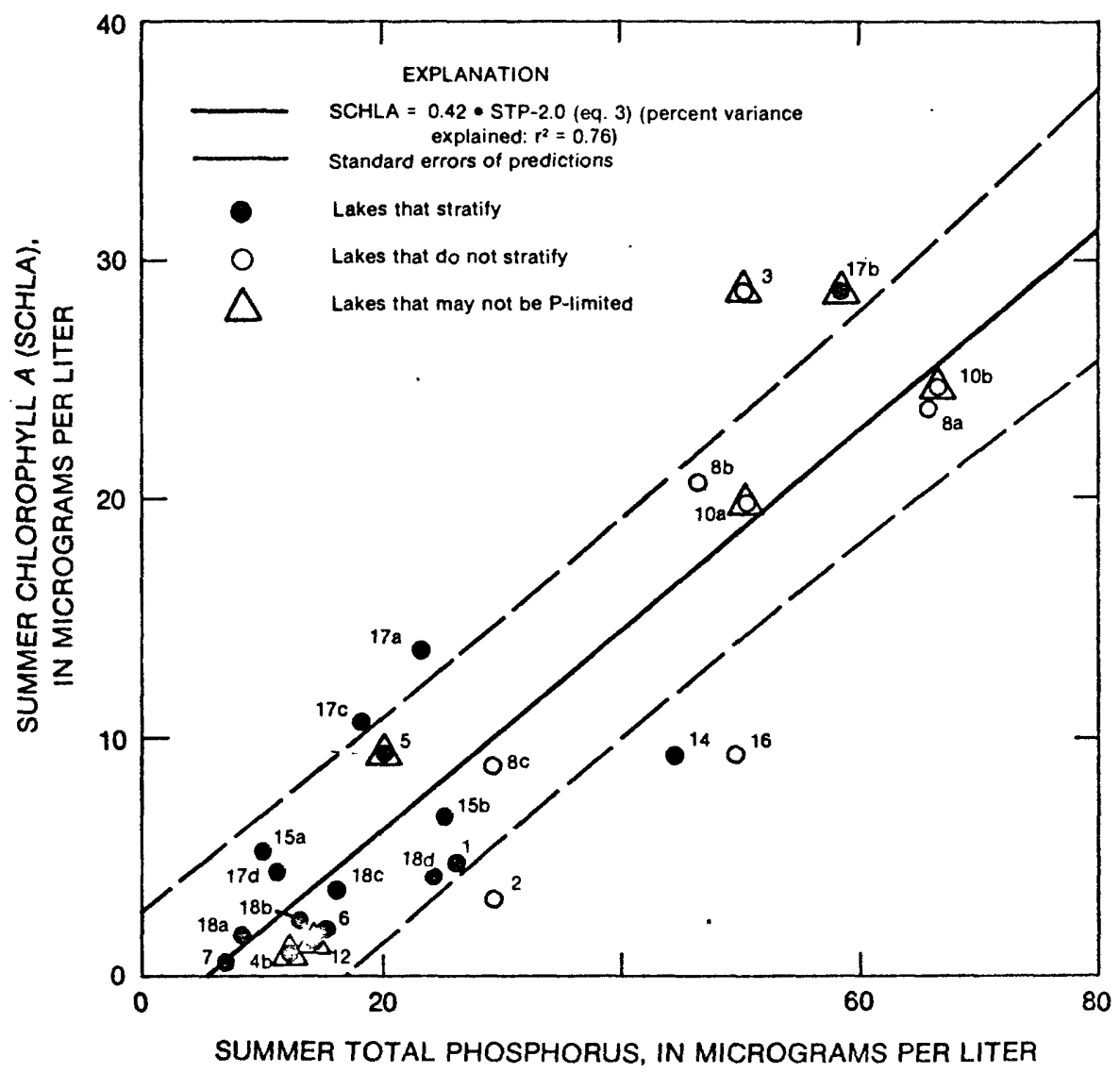

Figure 4. Relationship between summer chlorophyll a and summer total phosphorus concentrations. 
high total $P$ concentrations relative to the amount of $P$ actively involved in algal growth. Thus, the chlorophyll a levels would tend to be less than for stratified lakes with the same $P$ concentrations. We hypothesize the occurrence of this phenomenon in this region's lakes, but believe that the available data

for unstratified lakes do not justify separating the two types of lakes for the present analysis.

A second point for discussion is the behavior of lakes that may be $\mathrm{N}-1$ imited rather than P-limited during the summer growing season. One would expect that lakes with measured $N: P$ ratios of less than 10 would have a tendency as a group to plot below the regression 1 ine in figures 3 and 4 . Since such ratios would indicate an excess of $P$, there should be less algae per unit of $P$. There is no evidence of such a trend in figures 3 or 4 , however. Even lake observations with an average $\mathrm{N}: \mathrm{P}$ ratio less than the theoretically critical value of 7 ( 5 , $10 \mathrm{~b}, 17 \mathrm{~b})$ plot near or above the regression line. These few data suggest that average algal biomass, even in lakes that may sometimes be $\mathrm{N}-1$ imited during the summer growing season, is mainly determined (or is at least predictable) by the amount of total $P$. This relationship may change, however, for more nutrient-rich waters than are represented in this study, and caution is always advised (for example, see Forsberg, 1977).

Our results generally compare quite closely with those of other researchers for different geographic areas. A comparison of our equations 2 and 3 to similar relationships developed by others is shown in table 3 . Our equation 2 should be compared to Dillon and Rigler's equation and our equation 3 should be compared to Jones and Bachmann's equation due to the different seasons when total $P$ concentrations were measured. Based on these comparisons, all predictions are virtually identical until $P$ concentrations in the range of $40-50 \mu \mathrm{g} / \mathrm{L}$ are reached. There, the nonlinear relationships of the other researchers begin to depart substantially from ours. We believe that our relationship is, in fact, linear because of the relatively narrow range of $p$ levels represented by our data. Oglesby and Schaffner (1978) also found a linear relationship between $P$ and chlorophy 11 a for 13 New York lakes within a narrow range of $P$ concentrations. We tested $\log -\log$ transformations but, for the range of our data, they were essentially the same as the equations shown. We could not justify discarding observations such as 14 and 16 (fig. 4), which could change this result considerably. The tentative conclusion from this comparative evaluation is that, with the data evaluated, we are viewing restricted "windows" (figs. 3 and 4 ) in nonlinear relationships that are probably much like those developed by the other researchers from data with a wider spread in $P$ concentration. This is supportive of the often-reached general conclusion that there is a remarkably similar relationship between $P$ and algal productivity for lakes in many different regions of the world (Schindler, 1978).

For predicting chlorophyll a levels in Puget Sound region lakes, one could use any of the relationships in table 3 for the range of $P$ concentrations represented and get fairly similar results. However, we recommend using equations 2 and 3 , developed from this region's data, mainly because they are accompanied by a region-specific evaluation of uncertainty. Equation 3 is preferable because estimated errors are less when summer total $P$ concentrations are used. Predictions can be made directly from the graph of the regression line (fig. 4) or from 
TABLE 3. Comparison of regression models for estimating summer chlorophyll a concentrations from total phosphorus concentrations

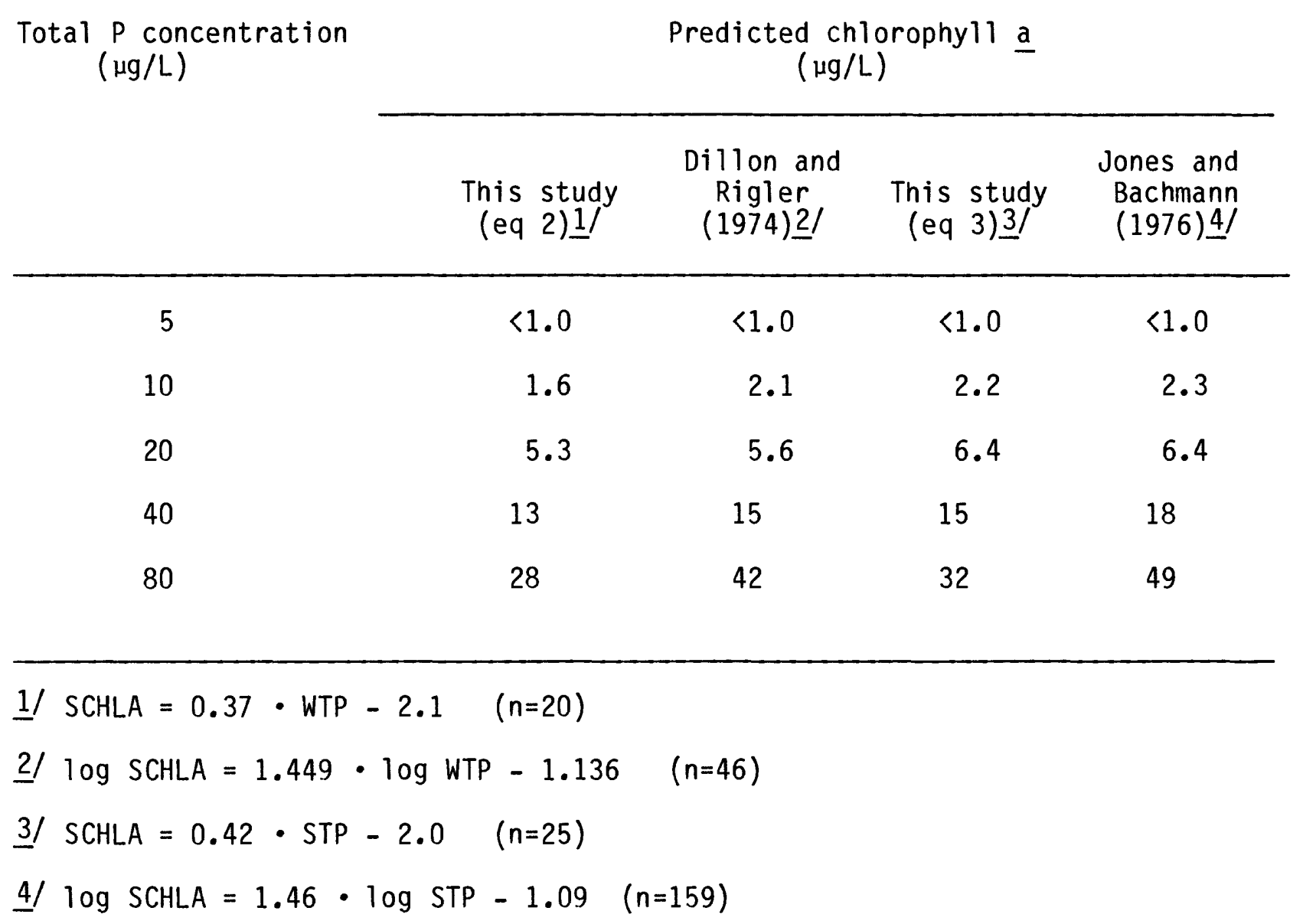


equation 3. Standard errors of prediction vary little for different $P$ levels and can generally be assumed equal to $\pm 5 \mu \mathrm{g} / \mathrm{L}$ chlorophy 11 a (at a 68 percent confidence level) throughout the range of $P$ levels represented $(5-65 \mu g / L)$. When necessary, predictions al so can be made from winter total $P$ (eq. 2), but the average standard error increases to about $\pm 7 \mu \mathrm{g} / \mathrm{L}$.

In some lakes, chlorophyll a levels may be consistently higher or lower than a regional average (regression line) at a given $P$ concentration (Smith and Shapiro, 1981). If present-day or historical data show a lake to be consistently higher or lower than average (based on the mean values for at least two years), the predicted chlorophyll a concentration at a new $P$ concentration should be determined as the regression estimate plus the positive or negative average deviation of the past observed values from the line. The same standard error of estimate should be used.

For predicting chlorophyll a levels for $P$ concentrations much beyond the range of our data, one should probably use the relationship of Jones and Bachmann (1976) or Dillon and Rigler (1974) and appropriate error estimates determined from their data.

\section{Lake-Water Clarity}

The clarity of lake water is easily tested by measuring Secchi-disc transparency. This measurement is obtained by lowering a $20 \mathrm{~cm}$ black and white disc vertically through the water to the greatest depth at which it is still visible. This is a particularly useful test of water quality because it is a visual measure of quality that is readily understood by most people.

The transparency of lake water is mainly affected by amounts of suspended algae and other particulate matter and by dissolved colored substances. There is generally a strong correlation between Secchi-disc transparency and the amount of algae in lake water as measured by chlorophyll a concentration. The relationship between Secchi-disc transparency and chlorophyll a concentration for lakes investigated in the Puget Sound region is shown in figure 5 .

Figure 5 illustrates the varying role of algae in affecting visual water quality. At low concentrations of chlorophyll a (approximately $5 \mathrm{\mu g} / \mathrm{L}$ and less), water transparency appears to be extremeTy sensitive to changes in amounts of algae. In this range, however, factors other than algae, such as dissolved colored substances, become much more important relative to algae in their effect on water transparency. This situation obscures the actual causes of variations in transparency between different lakes in this range. At higher chlorophyll a concentrations $(>5 \mu \mathrm{g} / \mathrm{L})$, on the other hand, the particulate matter associated with algae is usually the dominant factor affecting transparency. In this range, however, there is little change in transparency even with a large change in chlorophyll a concentration. Thus, even though algae are the main cause of reduced transparency in this range of high chlorophyll a concentrations, changes in amounts of algae may not produce readily noticeable changes in water clarity. Though figure 5 shows a useful descriptive relationship between chlorophyll a and Secchi-disc transparency that may aid interpretation of data for various Takes, we chose to concentrate on relationships between $P$ concentration (the fundamental cause of plankton productivity) and Secchi-disc 


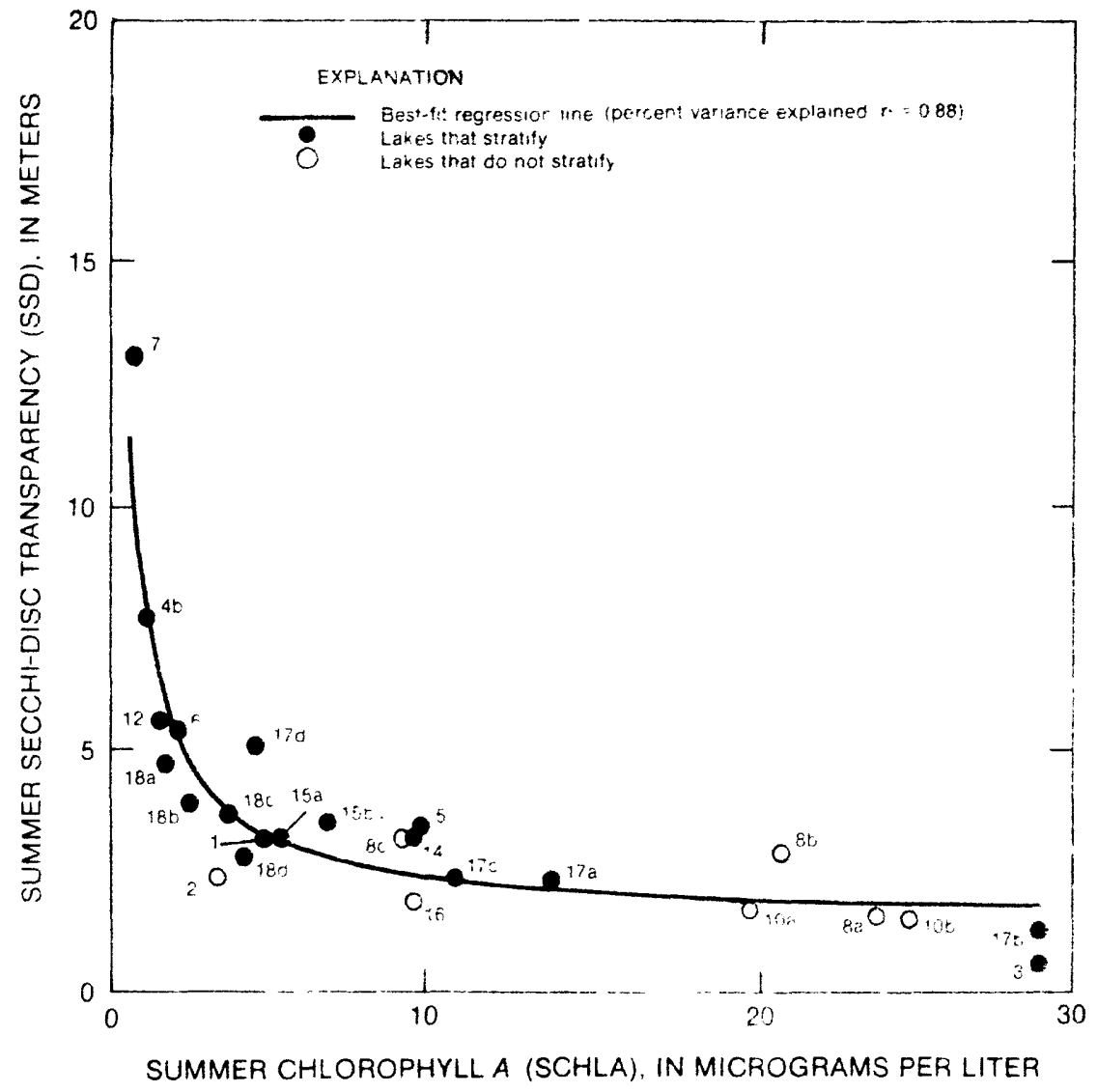

Figure 5. Relationship between summer Secchi-disc transparency and summer cholorophyll a concentration. 
transparency for predictive purposes. Only the relationship between summer total $P$ and Secchi-disc transparency was evaluated.

Figure 6 shows the general relationship between summer total P (STP) and summer Secchi-disc transparency (SSD) over the entire range of $P$ concentrations represented. Figure 7 shows part of the same data, but is restricted to total $P$

concentrations of $15 \mu \mathrm{g} / \mathrm{L}$ or greater, which we felt was the most practical range to focus on for decisionmaking purposes. The regression equation represented in figure 7 is as follows:

$$
\text { SSD }=4.2-0.05 \cdot S T P
$$

For deriving this relationship, both stratified and unstratified lakes were included, as indicated. Also indicated are lakes that may have been $\mathrm{N}-1$ imited, as determined by a range in ratios of summer inorganic $\mathrm{N}$ to dissolved $\mathrm{PO}_{4}-\mathrm{P}$ of less than 10 .

No systematic differences were apparent between stratified and unstratified lakes in the relationship of total $P$ to Secchi-disc transparency. This is in contrast to the relationship between total $P$ and chlorophyll $a$, in which unstratified lakes tended to have lower chlorophyll a concentrations than did stratified lakes with the same total $P$. This occurrence again may be explained by greater amounts of non-algal particulate matter in unstratified lakes due to their shallow, completely mixed character. With regard to water clarity, the non-algal particulate matter would reduce transparency in a similar manner as algae (and possibly also sorb biologically available $P$ ), thus eliminating any large differences between lakes that stratify and those that do not.

There also appear to be no differences between lakes that are clearly P-limited and lakes that may sometimes be $\mathrm{N}-1$ imited. Just as with the chlorophyll a relationship in figure 4, even the Secchi-disc observations for lakes with $N: P$ ratios less than $7(5,10 \mathrm{~b}, 17 \mathrm{~b})$, in which the influence of $P$ concentrations theoretically should be less, plot near the regression line in figure 7 .

Our results in this regard, also, agree fairly well with the findings of other researchers. A comparison of estimates from our relationship shown in figure 7 and a similar one developed by Rast and Lee (1978) for lakes throughout North America is shown in table 4. One might expect that the relationship of Rast and Lee (1978) would predict a greater Secchi-disc transparency for equal $P$ concentration value because they used annual means of total $P$ concentrations, which tend to be greater in near-surface waters than the summer concentrations we used. The only large difference between the two methods, however, occurs at high $P$ concentrations (see table 4 ).

For estimating the Secchi-disc transparency of a lake from a known or projected total $P$ concentration, the use of equation 4 (fig. 7 ) is the most appropriate approach for this region. Estimates can be made directly from the graphed regression line or from the equation. Standard errors of estimated Secchi-disc transparencies vary little over the range of $P$ concentrations represented and, therefore, can be taken to be $\pm 0.9 \mathrm{~m}$. As with chlorophyll a prediction, if a lake has a known history of having a higher or lower Secchi-disc 


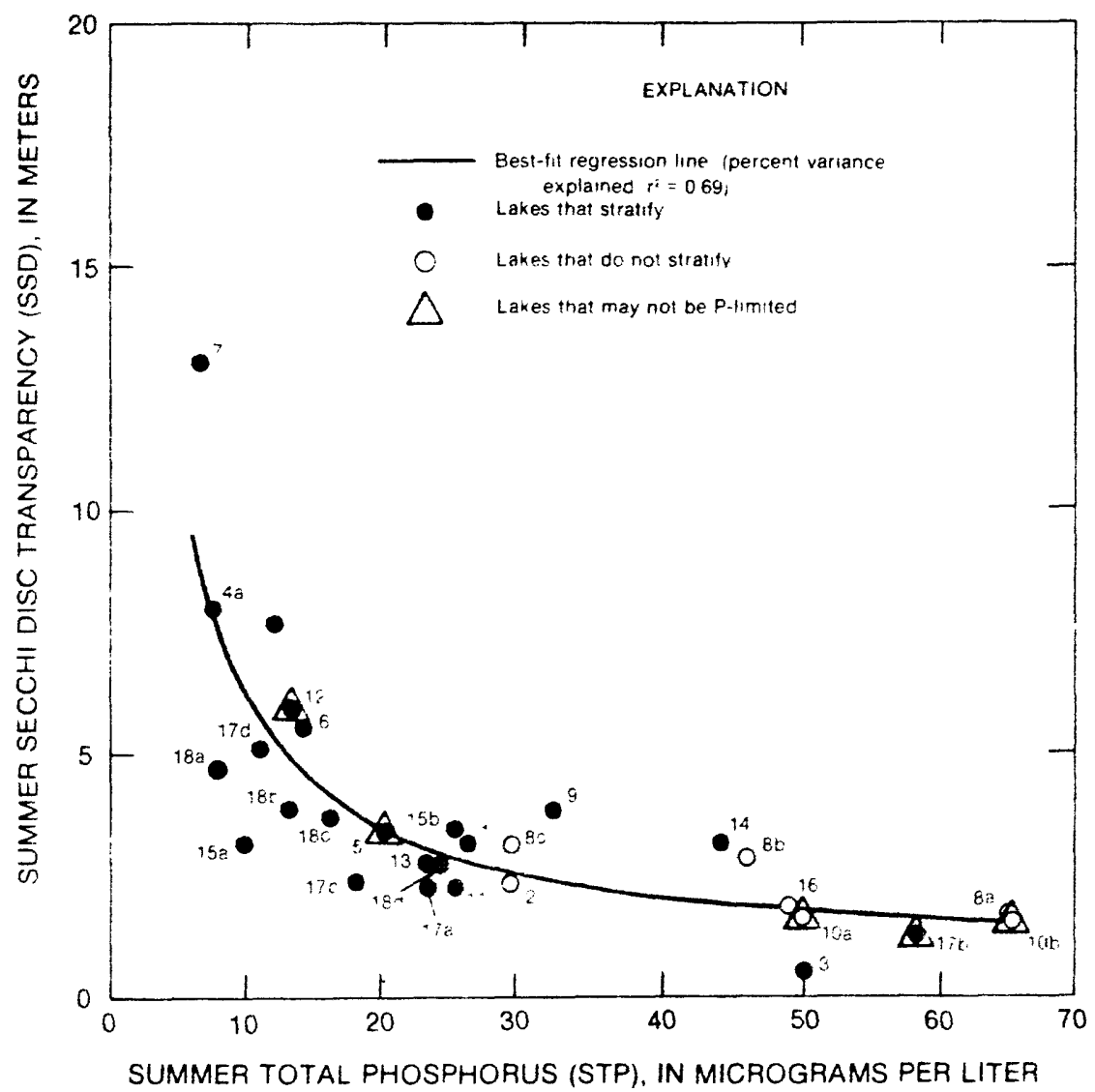

Figure 6. Relationship between summer Secchi-disc transparency and summer total phosphorus concentration 


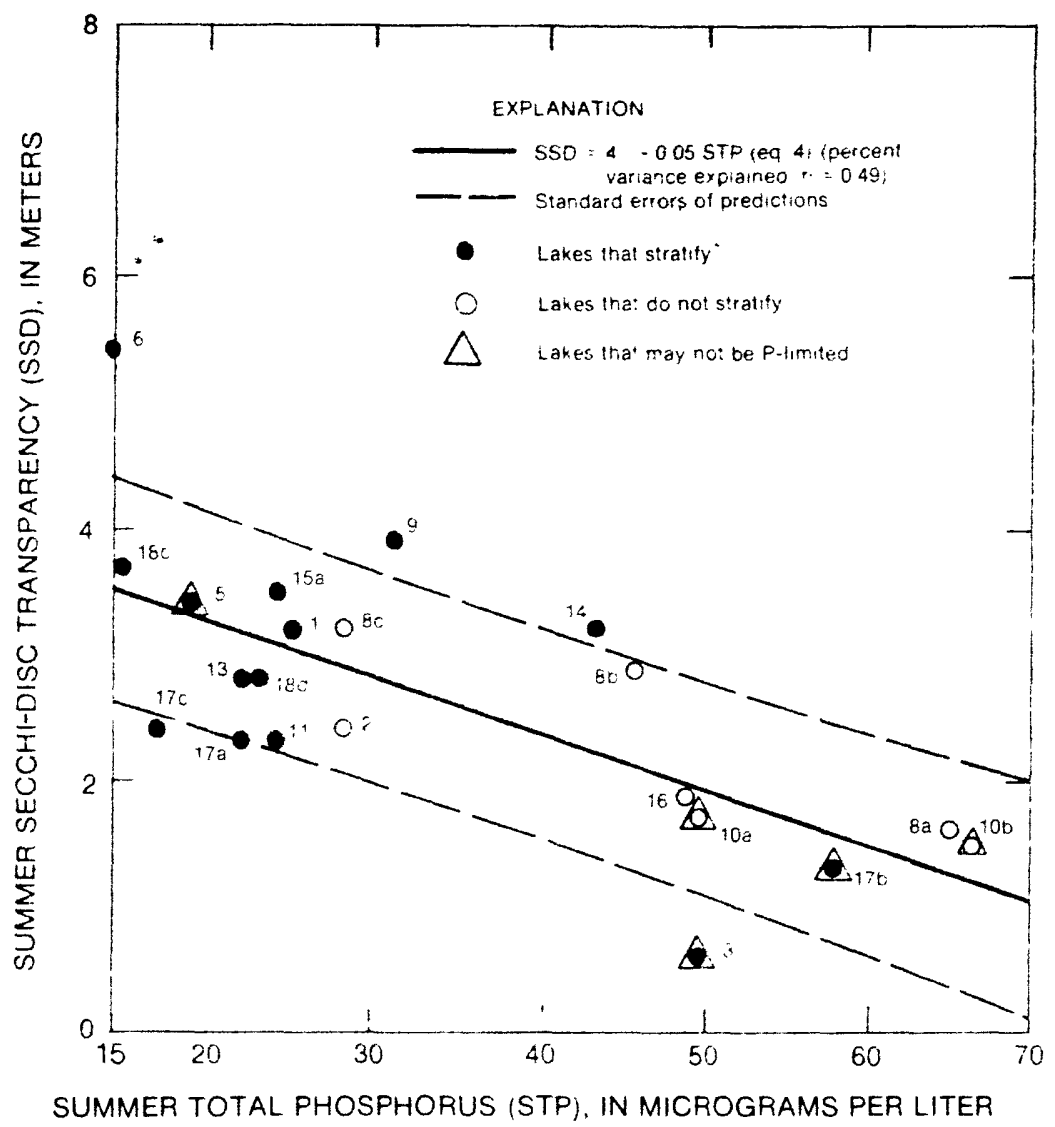

Figure 7. Relationship between summer Secchi-disc transparency and summer total phosphorus concentration for lakes with phosphorus concentrations of $15 \mathrm{ug} / \mathrm{L}$ or greater. 
TABLE 4. Comparison of regression models for estimating summer Secchi-disc transparency from total phosphorus concentration

Total $P$ concentration $(\mu \mathrm{g} / \mathrm{L})$

(n)

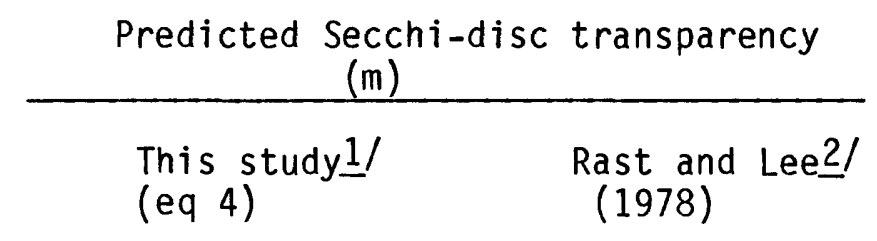

15

3.6

3.2

30

2.8

2.5

60

1.3

1.9

1/ SSD $=4.3-0.5 \cdot \operatorname{STP} \quad(n=28)$

2f $\log$ SSD $=0.359 \cdot \log$ ATP $+0.925 \quad(n=53)$

where ATP is the annual mean total $P$ concentration for the entire lake 
transparency than the regional average, then the type of compensation discussed previously for chlorophyll a prediction (p. 15) may be warranted. For predicting Secchi-disc transparencies in waters having total $P$ concentrations less than $15 \mathrm{\mu g} / \mathrm{L}$, one could make an interpretive judgment using figure 6 ; however, estimates for such low $P$ levels involve much uncertainty. On the average, a lake with an average summer total $P$ concentration of less than $15 \mu \mathrm{g} / \mathrm{L} \mathrm{will}$ have a Secchi-disc transparency greater than $4 \mathrm{~m}$. In contrast, lakes that

have an average summer total $P$ concentration greater than $70 \mu \mathrm{g} / \mathrm{L}$ will usually have a Secchi-disc transparency near $1 \mathrm{~m}$ or less.

\section{General Water-Quality Groups}

When general effects of large changes in $P$ concentrations need to be evaluated or when many lakes need to be quickly categorized on a common scale, an evaluation by general water-quality characteristics may be more useful than specific estimates from the regression models. For such purposes we suggest a simple system of water-quality groups based on summer $P$ concentrations, as shown in table 5. A similar table was originally developed by Dillon and Rigler (1975), but we modified it for the Puget Sound region to fit both the results of this study and general observations regarding recreational suitability, oxygen depletion, and fisheries. Though table 5 describes more aspects of water quality than the regression equations, it is still limited to effects of phosphorus on open-water productivity. Near-shore growth of macrophytes, for example, is not considered. Furthermore, the general groups in table 5 must be regarded as a continuum--a lake falling in the upper range of group B would often have characteristics most like group $C$, for example. These limitations should be kept in mind when applying this very general rating system.

\section{CONCLUSIONS}

1. A large majority of Puget Sound region lakes have nitrogen-to-phosphorus ratios that clearly favor limitations of algae growth by phosphorus.

2. Even lakes that possibly are nitrogen-limited have chlorphyll a concentrations and Secchi-disc transparencies that are best predicted from phosphorus amounts alone.

3. Summertime concentrations of total phosphorus in near-surface waters, which averaged 7 percent of winter-spring phosphorus levels for lakes that stratify, are a better indicator of water clarity and algae concentrations than are winter-spring concentrations. In lakes that do not stratify, winterspring and summer phosphorus concentrations may average about the same.

4. Knowledge of mean summertime total phosphorus concentrations explains 76 percent of the variance in mean summer chlorophyll a concentrations that were observed in the lakes evaluated. The standard er ror of prediction from the regression equation is $\pm 5 \mu \mathrm{g} / \mathrm{L}$.

5. Knowledge of mean summertime total phosphorus concentrations explains 69 percent of the variance in mean summer Secchi-disc transparencies. For 
TABLE 5. Characteristic relationships between lake-water phosphorus concentrations, and general lake-water quality

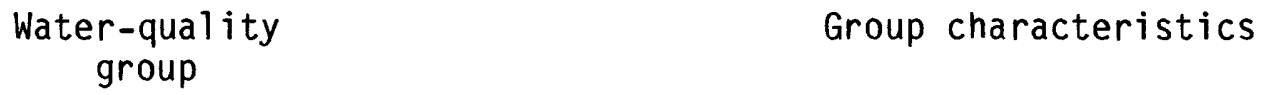

B

STP $=10$ to $20 \mu \mathrm{g} / \mathrm{L}$
Moderate algal productivity; generally compatible with all recreational uses. Algal blooms are occasional, but generally of low to moderate intensity. 0xygen depletion is common in the bottom waters and coldwater fisheries may be endangered in some shallow lakes. In many lakes, however, the fishery may be enhanced by the increased productivity. Secchi-disc transparency is usually 3-5 m, and chlorophyll a averages 2-6 $\mu \mathrm{g} / \mathrm{L}$ in most lakes.

$C$
STP $=20$ to $30 \mu \mathrm{g} / \mathrm{L}$

STP greater than $30 \mathrm{\mu g} / \mathrm{L}$
Moderately high algal productivity; still compatible with most recreational uses, but algal blooms are more frequent and intense, and oxygen depletion is more serious. This can increase fisheries problems, though productivity may still be enhanced. Water is often somewhat murky and Secchi-disc transparency is usually 2-4 m. Chlorophyll a usually averages 4-12 $\mathrm{\mu g} / \mathrm{L}$.

\begin{tabular}{cl}
\hline D & High algal productivity; lake suitability for most \\
recreational uses is often impaired by frequent and \\
intense algal blooms which may form floating scums. \\
STP greater than & The water often takes on a pea soup" color resulting \\
$30 \mathrm{\mu g} / \mathrm{L}$ & in extremely murky water. Fish kills may be common \\
because of depleted oxygen especially in shallow lakes. & Secchi-disc transparency is generally less than $3.0 \mathrm{~m}$, \\
& and chlorophyll a concentration is usually greater than \\
& $10 \mu \mathrm{g} / \mathrm{L}$.
\end{tabular}


lakes with total phosphorus concentrations of $15 \mu \mathrm{g} / \mathrm{L}$ or greater, summertime total phosphorus concentrations explained 49 percent of the sample variance. The standard error or prediction of Secchi-disc transparency for lakes with total phosphorus averaging $15 \mu \mathrm{g} / \mathrm{L}$ or greater is $\pm 0.9 \mathrm{~m}$.

6. Regression relationships that were developed in this study between total phosphorus and both chlorophyll a and Secchi-disc transparency produce predictions that generally agree with predictions from similar relationships developed by other researchers for different groups of lakes.

7. Numerical predictions of chlorophyll a concentrations and Secchi-disc transparencies associated with particular phosphorus concentrations can be supplemented by more general and descriptive relationships that include dissolved oxygen depletion, recreational suitability, and fisheries quality, to give a fairly comprehensive view of the character of a lake at a specific mean phosphorus concentration.

\section{LITERATURE CITED}

Birch, P. B., 1976. The relationship of sedimentation and nutrient cycling to the trophic status of four lakes in Lake Washington drainage basin. Seattle, Wash., University of Washington, Ph.D. thesis, 199 pp.

Bortleson, G. C., G. T. Higgins, and G.W. Hill, 1974. Data on selected lakes in Washington, part 2. State of Washington, Department of Ecology, Water-Supply Bulletin 42, $145 \mathrm{pp}$.

Bortleson, G. C., G. T. Higgins, J. B. McConnell, and J. K. Innes, 1976. Data on selected lakes in Washington, part 3. State of Washington, Department of Ecology, Water-Supply Bullet in 42, 143 pp.

Chapra, S. C., and S. J. Tarapchak, 1976. A chlorophyll a model and its relationship to phosphorus loading plots for lakes. Water Resources Research(12):1260-1264.

Davis, J. I., J. M. Buffo, D. S. Sturgil, and R. I. Matsuda, 1978. A study of the trophic status and recommendations for the management of Lake Meridian. Municipality of Metropolitan Seattle, 156 pp.

Dillon, P. J., and F. H. Rigler, 1974. The phosphorus-chlorophyll relationship in lakes. Limnology and Oceanography(19):767-773.

1975. A simple method for predicting the capacity of a lake for development based on lake trophic status. Fisheries Research Board of Canada Journal (32):1519-1530.

Dion, N. P., G. C. Bortleson, J. B. McConnell, and J. K. Innes, 1976. Data on selected lakes in Washington, part 5. State of Washington, Department of Ecology, Water-Supply Bulletin 42, 125 pp. 
Dion, N. P., G. C. Bortleson, and J. K. Innes, 1980. Data on Selected Lakes in Washington, part 6 . State of Washington, Department of Ecology, Water-Supply Bulletin 42, $125 \mathrm{pp}$.

Forsberg, Curt, 1977. Nitrogen as a Growth Factor in Fresh Water. Progress in Water Technology(8):pp275-290.

Gilliom, R. J., 1981. Estimation of Background Loadings and Concentrations of Phosphorus for Lakes in the Puget Sound Region, Washington. Water Resources Research 17(2):410-420.

Gilliom, R. J., 1982. Estimation of Nonpoint Sources of Phosphorus to Lakes in the Puget Sound Region, Washington. U.S. Geological Survey Open-File Report 82-161, $36 \mathrm{pp}$.

Hendrey, G. R., 1973. Productivity and Growth Kinetics of Natural Phytoplankton Communities in four Lakes of Contrasting Trophic State. Seattle, Wash., University of Washington, Ph.D. thesis, $263 \mathrm{pp}$.

Issac, G. W., R. I. Matsuda, and J. R. Welker, 1966. A Limnological Investigation of Water Quality Conditions in Lake Summamish. Municipality of Metropolitan Seattle. Water-Quality Series No. 2, 47 pp.

Jones, J.R., and R. W. Bachmann, 1976. Prediction of Phosphorus and Chlorophyll Levels in Lakes. Water Pollution Control Federation Journal (48):2176-2182.

Mc Connel1, J. R., G. C. Bortleson, and J. K. Innes, 1976. Data on Selected Lakes in Washington, part 4. State of Washington, Department of Ecology. Water-Supply Bulletin 42, 141 pp.

Oglesby, R. T., 1969. Effects of Controlled Nutrient Dilution on the Eutrophication of a Lake. In: Eutrophication: Causes, Consequences, Correctives. National Academy of Sciences, Natural Resources Council, Publication 1700, pp. 483-493.

Oglesby, R. T., and W. R. Schaffner, 1978. Phosphorus Loadings to Lakes and Some of Their Responses. Part 2--Regression Models of Summer Phytoplankton Standing Crops, Winter Total P, and Transparency of New York Lakes with Known Phosphorus Loadings. Limnology and Oceanography(23):135-145.

Orsborn, J.F., J.E. Ongerth, G. C. Bailey, S. K. Bhagat, W. H. Funk, C. C. Lomax, and W. C. Mih, 1975. Hydraulic and Water Quality Research Studies and Analysis of Capitol Lake Sediment and Restoration Problems. Olympia, Washington. Pullman, Washington State University.

Perkins, M. A., E. B. Welch, and J. 0. Gabrielson, 1979. Limnological Characteristics of Long Lake Kitsap County, Washington. In: Limnological and Socioeconomic Evaluation of Lake Restoration Projects, EPA Research and Development, EPA-600/3-79-005, pp. 96-118. 
Rast, Walter, and G. F. Lee, 1978. Summary Analysis of the North American (U.S. Portion) OECD Eutrophication Project. Nutrient Loading-Lake Response Relationships and Trophic State Indices. U.S. Environmental Protection Agency, Ecological Research Series, EPA-600/3-78-008, 455 pp.

Sakamoto, M., 1966. Primary Production by Phytoplankton Community to Some Japanese Lakes and Its Dependence on Lake Depth. Arch. Hydrobio.(62): $1-28$.

Schindler, D. W., 1978. Factors Regulating Phytoplankton Production and Standing Crop in the World's Freshwaters. Limnology and Oceanography(23) pp. 478-486.

Schindler, D. W., and E. J. Fee, 1974. Experimental Lakes Area, Whole Lake Experiments in Eutrophication. Fisheries Research Board of Canada Journal (31): 937-953.

Schindler, D. W., E. J. Fee, and T. Ruszcyzynski, 1978.a Phosphorus Input and Its Consequences for Phytoplankton Standing Crop and Production in the Experimental Lakes Area and in Similar Lakes. Fisheries Research Board of Canada Journal (35):190-196.

Smith, V. H., and Joseph Shapiro, 1981. Chlorophyll-Phosphorus Relations in Individual Lakes--Their Importance to Lake-Restoration Strategies. Environmental Science and Technology(15):444-451.

Stamnes, R. L., 1972. The Trophic State of Three Lakes Related Nutrient Loading. Seattle, Wash., University of Washington, Masters Thesis, 86 pp.

U.S. Geological Survey, 1979. Water Resources Data for Washington, Water Year 1978. Volume 1, Western Washington. U.S. Geological Survey Water-Data Report WA-78-1, $431 \mathrm{pp}$.

URS Company, 1977. Big Lake Restoration Study: Final Report for Skagit County Planning Department, $66 \mathrm{pp}$.

Vollenweider, R. A., 1968. Scientific Fundamentals of the Eutrophication of Lakes and Flowing Waters, with Particular Reference to Phosphorus and Nitrogen as Factors in Eutroophication. Paris, Organization for Economic Coooperation and Development Technical Report, PAS/CSI/68(27):1-182.

Walker, W. W., Jr., 1980. Use of Hypolimnetic 0xygen Depletion Rate as a Trophic State Index for Lakes. Water Resources Research (15):1463-1470.

Welch, E. B., D. N. Given, and J. C. Neel, 1977. Water Quality Problems and Alternatives for the Restoration of Lake Ballinger. Part 2--The Lake. Municipality of Metropolitan Seattle, $120 \mathrm{pp}$.

Welch, E. B., and M. A. Perkins, 1979. Oxygen Deficit-Phosphorus Loading Relation in Lakes. Water Pollution Control Federation Journal(51):2823-2828. 
Welch, E. B., M. A. Perkins, Dennis, Lynch, and Peter Hufschmidt, 1979. Internal Phosphorus Related to Rooted Macrophytes in a Shallow Lake. In: Aquatic Plants, Lake Management, and Ecosystem Consequences of Lake Harvesting, Proceedings of a Conference, Madison, Wisconsin, pp 81-99.

Welch, E. B., T. Wiederholm, D. E. Spyridakis, and C. A. Rock, 1975. Nutrient Loading and Trophic State of Lake Sammamish, Washington. Seattle, Univ. of Washington, Department of Civil Engineering, $18 \mathrm{pp}$.

Welzel, R. G., 1975. Limnology. Philadelphia, W. B. Saunders Co., 743 pp. 